\title{
Pengembangan Bahan Ajar Berbasis PBL Pada Pelajaran Ekonomi Untuk Meningkatkan Keterampilan Sosial Peserta Didik SMA
}

\author{
RIA RAHMAWATI, SUKIDJO \\ Jurusan Pendidikan IPS UNY, Universitas Negeri Yogyakarta \\ Email : che_ria.rahma@yahoo.co.id, sukidjo@uny.ac.id
}

\begin{abstract}
Abstrak
Penelitian ini bertujuan menghasilkan produk bahan ajar berbasis problem based learning untuk meningkatkan keterampilan sosial peserta didik pada mata pelajaran ekonomi. Keterampilan sosial dalam penelitian ini meliputi aspek bekerjasama, komunikasi, dan tanggungjawab sosial. Penelitian ini merupakan penelitian pengembangan (R\&D) dengan pengembangan yang mengadaptasi model Dick\&Carey. Validasi dilakukan oleh 2 ahli materi dan 2 ahli media. Uji coba dilakukan 2 tahap, yaitu uji coba terbatas dan uji coba lapangan. Berdasarkan analisis data dengan menggunakan MANOVA, diketahui terdapat perbedaan keterampilan sosial dan prestasi belajar antara pembelajaran tanpa bahan ajar berbasis problem based learning dengan pembelajaran bahan ajar berbasis problem based learning.
\end{abstract}

Kata Kunci : Bahan ajar berbasis problem based learning, keterampilan sosial.

\section{Abstract}

This study aimed to produce teaching materials on problem based learning to improve the social skills of students in economic subjects. Social skills in the study it includes aspects of collaboration, communication, and social responsibility. The study was conducted using $R$ and D method with the development of adapting from dick and carey model. The data validation was analized by 2 experts and 2 expert media material. The test is done 2 stages, namely limited testing and field trials. Based on data analysis using MANOVA, there are known differences in social skills and learning achievement among learning without teaching materials based on problem based learning with problem -based learning teaching materials based learning.

Keywords : Instructional Materials on Problem Based Learning, Social Skills. 


\section{PENDAHULUAN}

Pendidikan sebagai investasi sumber daya manusia bagi suatu negara. Pendidikan merupakan cermin kemajuan kehidupan suatu negara. Perbaikan kurikulum sebagai salah satu cara dalam meningkatkan kualitas pendidikan di Indonesia. Kurikulum yang berkembang merupakan cermin dari pendidikan yang dibangun dalam suatu negara, yang direalisasikan dalam pembelajaran.

Kurikulum yang digunakan sekolah saat ini adalah kurikulum 2013. Kurikulum 2013 PP No.32 pasal 77D tahun 2013 Tentang Standar Nasional Pendidikan menyatakan bahwa "kompetensi dasar yang ingin dicapai adalah sikap spritual, sikap sosial, pengetahuan dan keterampilan dalam muatan pembelajaran, mata pelajaran atau mata kuliah sesuai dengan kompetensi inti." Keterampilan sosial merupakan kemampuan peserta didik dalam mengatasi diri sendiri dan orang lain ketika berada di masyarakat. Kompetensi keterampilan merupakan kecakapan yang harus dimiliki oleh peserta didik, seperti kecakapan dalam menyelesaikan tugas, berkomunikasi membaca atau menulis. Keterampilan sosial harus dimiliki peserta didik dalam kehidupannya untuk berhubungan dengan orang lain $\mathrm{Hal}$ itu sebagai usaha dalam memberdayakan semua warga Negara Indonesia menjadi manusia berkualitas, sehingga mampu dan proaktif menjawab tantangan zaman yang selalu berubah. Hamalik (2005, p.17) menyatakan pembelajaran yang efektif adalah pembelajaran yang menyediakan kesempatan kepada peserta didik untuk belajar mandiri, dengan melakukan aktifitas belajar peserta didik mampu memperoleh pemahaman sendiri.

Ilmu Pengetahuan Sosial (IPS) merupakan kajian ilmu sosial antara hubungan manusia dengan lingkungan sosial dan alam. Ilmu Pengetahuan Sosial (IPS) bertujuan untuk mengembangkan potensi peserta didik agar peka terhadap permasalahan sosial yang terjadi di masyarakat, memiliki sikap mental positif untuk perbaikan ketimpangan, dan terampil mengatasi setiap masalah yang terjadi sehari-hari, baik terhadap dirinya maupun masyarakat. Mata pelajaran ekonomi merupakan salah satu kajian dalam Ilmu Pengetahuan Sosial (IPS).

Bahan ajar yang ada di sekolah sebagian besar masih berupa soal-soal pilihan ganda yang hanya memberikan kesempatan peserta didik untuk hafalan sebagai pencapaian kompetensi kognitif. Bahan ajar cetak yang beredar berisi 20 pilihan ganda, 10 esay dengan jawaban singkat dan perintah pencarian artikel. Pencapaian aspek kompetensi afektif dapat dilakukan dalam pembelajaran dengan bahan ajar berbasis problem based learning untuk mengembangkan keterampilan sosial berupa komunikasi, tanggungjawab sosial, dan bekerjasama. Pemilihan bahan ajar yang tepat akan memberikan fasilitas belajar yang baik untuk peserta didik dalam mencapai kompetensi pendidikan yang diharapkan.

Pembelajaran menggunakan bahan ajar berbasis problem based learning dilakukan dengan berkelompok untuk memecahkan permasalahan yang disajikan, menganalisis dan membuat laporan.

Ilmu ekonomi dapat dibedakan menjadi ekonomi normatif dan ekonomi positif (Karyana, 2006, p.2). Ekonomi normatif merupakan aspek ilmu ekonomi yang membahas pertimbangan etika dan nilai yang akan dilakukan melalui kebijakan-kebijakan ekonomi yang diambil untuk mencapai tujuan tertentu, menempatkan masalah ekonomi sebagaimana mestinya, yaitu mengambil sikap dalam kebijakan tidak boleh memihak tetapi mempertimbangkan baik-buruk dampak dari kebijakan tersebut. Sedangkan ekonomi positif merupakan ilmu ekonomi yang membahas mengenai fakta, situasi dan hubungan yang terjadi dalam kehidupan ekonomi yang sebenarnya.

Pembelajaran problem based learning mencoba memberikan fasilitas kepada peserta didik dalam ilmu ekonomi positif sebagai dasar permasalahan dan ilmu ekonomi normatif sebagai pembelajaran peserta didik dalam mencari solusi terhadap permasalahan yang sesuai dengan konsep-konsep ilmu ekonomi. Pembelajaran itu akan menjadikan peserta didik terbiasa dalam memecahkan permasalahan ke- 
hidupan. Model problem based learning dapat dilakukan dengan latihan-latihan yang perlu diakomodasikan dalam bahan ajar berbasis problem based learning untuk melatih peserta didik dalam penerapan ilmu ekonomi positif dan ilmu ekonomi normatif.

Permasalahan kehidupan sehari-hari dalam proses belajar terkadang hanya menjadi sebuah informasi saja bagi peserta didik. Permasalahan tersebut seharusnya dapat dikaitkan dengan konsep-konsep ilmu yang dimiliki oleh peserta didik. Proses belajar menggunakan bahan ajar banyak memberikan latihan soal-soal pilihan ganda yang terbatas pada hafalan teori dan jawaban singkat, sehingga pengembangan pengetahuan peserta didik untuk mengungkapkan ide-ide dan menganalisis dengan pengetahuan yang telah dimiliki masih kurang.

Perubahan tingkah laku tersebut merupakan hasil proses belajar yang dijalani oleh peserta didik, seperti yang diungkapkan oleh Harefa (2004, p.17) "tugas pertama manusia dalam proses menjadi dirinya yang sebenarnya adalah menerima tanggungjawab untuk menjadi pembelajar, bukan hanya di gedung sekolah dan perguruan tinggi, tetapi terlebih penting lagi dalam konteks kehidupan".

Bahan ajar (Depdiknas, 2008, p.6) adalah segala bentuk bahan yang digunakan untuk membantu guru/instruktor dalam melaksanakan kegiatan belajar mengajar.

Bahan ajar berbasis problem based learning dikembangkan dengan harapan dapat menjadi bahan ajar yang dapat memfasilitasi peserta didik dalam mencapai kompetensi afektif yaitu keterampilan sosial, dengan mempelajari permasalahan kehidupan nyata yang disajikan sebagai bahan belajar.

Pengembangan bahan ajar memiliki beberapa manfaat yaitu manfaat untuk guru dan peserta didik (Depdiknas, 2008, p.9).

\section{Manfaat bagi guru}

Beberapa manfaat pengembangan bahan ajar untuk guru yaitu pertama, guru dapat mengembangkan bahan ajar yang sesuai tuntutan kurikulum dan sesuai dengan kebutuhan belajar peserta didik. Kedua, guru dapat memiliki bahan ajar yang dapat membantu dalam pelaksanaan kegiatan pembelajaran. Ketiga, bahan ajar menjadi lebih bervariasi dan lebih banyak untuk menjadi referensi dalam pembelajaran, guru dapat menyesuaikan dengan kompetensi dan tujuan pembelajaran yang ingin dicapai. Keempat, menambah khasanah pengetahuan dan pengalaman guru dalam menulis bahan ajar. Kelima, bahan ajar akan mampu membangun komunikasi pembelajaran yang efektif antara guru dengan peserta didik, karena peserta didik akan merasa lebih percaya kepada gurunya.

Manfaat pengembangan bahan ajar untuk guru secara tidak langsung tidak hanya bermanfaat untuk pengembangan pembelajaran, tetapi kualitas guru dapat meningkat dengan pengembangan keterampilan dan kreativitas yang dimiliki oleh guru. Hal tersebut akan menjadikan proses pembelajaran yang inovatif, sehingga kompetensi pendidikan dapat tercapai.

\section{Manfaat bagi peserta didik}

Beberapa manfaat pengembangan bahan ajar bagi peserta didik yaitu, pertama kegiatan pembelajaran menjadi lebih menarik, peserta didik dapat memperoleh variasi kegiatan pembelajaran. Kedua, peserta didik akan lebih banyak mendapatkan kesempatan untuk belajar secara mandiri dan mengurangi ketergantungan terhadap guru (guru sebagai fasilitator). Ketiga, peserta didik akan mendapatkan kemudahan dalam mempelajari setiap kompetensi yang harus dikuasainya.

Menurut Arends (2012, p.396) problem based learning merupakan pemberian berbagai situasi permasalahan yang autentik dan bermakna kepada peserta didik, sebagai landasan untuk investigasi dan penyelidikan peserta didik.

Problem based learning merupakan pembelajaran yang menjadikan masalah sebagai bahan belajar di kelas. Pembelajaran yang menjadikan guru harus kreatif dalam membawa peserta didik untuk mengenali, memahami dan menganalisis sebuah masalah yang harus diselesaikan dengan konsep-konsep ilmu. Hal ini akan menjadikan peserta didik belajar aktif. 
Di dalam proses pembelajaran problem based learning peserta didik dapat mengembangkan keterampilan sosial dengan bekerjasama dan melakukan presentasi dari hasil pemecahan masalah yang diberikan.

Karateristik problem based learning yang lain yaitu (Riyanto, 2010, p.290) pertama, titik awal pembelajaran sebaiknya sebuah masalah. Pembelajaran dirancang dengan pemberian permasalahan kehidupan sehari-hari sebagai bahan belajar untuk mendapatkan konsep materi yang akan dipelajari. Kedua, berpusat pada peserta didik dan menekankan pembelajaran mandiri. Pembelajaran tidak terfokus pada guru, tetapi peserta didik dapat belajar menemukan konsep secara mendiri dengan arahan dari guru. Ketiga, dilakukan secara berkelompok. Pembelajaran dilakukan secara berkelompok untuk mencari solusi dari permasalahan secara bersama-sama.

Menurut Arends (2012, p.411) ada 5 langkah dalam melaksanakan pelajaran problem based learning, yaitu memberikan orientasi tentang permasalahannya kepada peserta didik, mengorganisasikan peserta didik untuk meneliti, membantu investigasi mandiri dan kelompok, mengembangkan dan mempresentasikan, menganalisis dan mengevaluasi proses mengatasi masalah.

Bahan ajar berbasis problem based learning merupakan bahan ajar yang memberikan bahan untuk pembelajaran peserta didik dari sebuah permasalahan yang ada dalam kehidupan sehari-hari, kemudian dianalisis dengan konsep ilmu pengetahuan. Dalam problem based learning menurut Amir (2009, p.47) fungsi pendidik bukan lagi "penguasa di atas panggung kelas, tapi memandu dari pinggir". Bahan ajar berbasis problem based learning memberikan kesempatan kepada peserta didik untuk belajar mandiri dengan menyelesaikan permasalahan dalam kehidupan sehari-hari yang dapat dilakukan secara berkelompok.

Keterampilan sosial merupakan bagaimana menangani emosi dengan baik ketika berinteraksi dengan orang lain (Riyanto, 2010, p.256), sedangkan menurut Goleman (2004, p.404) keterampilan sosial adalah kemampuan untuk mengendalikan diri menangani emosi dengan baik ketika berhubungan dengan orang lain, memahami dengan bijak dalam hubungan antara sesama manusia serta menyelesaikan konflik dalam suatu hubungan atau masyarakat.

Menurut Balton (Zuchdi, 2010, p.112) keterampilan sosial mencakup kecakapan berkomunikasi dan bekerjasama. Kecakapan berkomunikasi merupakan kemampuan seseorang dalam menyampaikan pendapat baik secara lisan ataupun tertulis. Kecakapan bekerjasama memberikan kemampuan dalam memecahkan masalah secara kolaborasi. Keterampilan tersebut bagian dari seseorang dalam menjalin hubungan baik dengan orang lain.

\section{METODE}

\section{Waktu dan Tempat Penelitian}

Penelitian dan pengembangan ini dilakukan mulai bulan Februari sampai Mei 2014. Uji coba dilakukan di SMA N 1 Godean. Subjek uji coba terbatas 9 peserta didik. Setelah direvisi hasil dari uji coba terbatas kemudan dilakukan di Uji coba lapangan dengan 30 peserta didik yang berbeda dari subjek uji coba terbatas.

\section{Model Pengembangan}

Penelitian yang dilakukan menggunakan metode penelitian dan pengembangan atau (research and development). Penelitian pengembangan atau research and development (R\&D) adalah suatu proses atau langkahlangkah untuk mengembangkan suatu produk baru atau menyempurnakan produk yang telah ada baik berupa perangkat keras atau perangkat lunak (Sukmadinata, 2013, p.164). Penelitian pengembangan dilakukan untuk menghasilkan produk bahan ajar berbasis problem based learning berdasarkan kurikulum 2013 yang menggunakan pembelajaran konstektual. Sehingga bahan ajar ini bisa menjadi inovasi dalam pendidikan.

Model pengembangan dalam penelitian ini mengadaptasi dari 10 langkah model pengembangan Dick\&Carey yaitu, Dick\&Carey (2005, P.6) yaitu: Identify intructional goal, Conduct instructional Analysis, Analyze learners 
and contexts, Write performance objectives, Develop assessment instruments, Develop instructional stategy, Develop and select instructional materials, Design and conduct formative evaluation of instruction, Revise instruction and Design and conduct summative evaluation.

Langkah-langkah model pengembangan Dick\&Carey tersebut diadaptasi menjad 5 tahap yaitu:

\section{Tahap Analisis Kebutuhan}

Pada tahap ini dilakukan kajian mengenai kebutuhan untuk mendapatkan informasi yang relevan terkait dengan pengembangan bahan ajar berbasis problem based learning dengan melakukan analisis studi pustaka, analisis kurikulum, dan observasi di lapangan. Analisis kebutuhan tersebut dilakukan untuk mengetahui kebutuhan peserta didik dalam perkembangan kurikulum dan pembelajaran yang sesuai dengan tujuan pendidikan nasional. Keadaan yang ada di lapangan bahwa pembelajaran belum konstektual dan masih terfokus untuk pencapaian kompetensi kognitif.

\section{Tahap Desain Produk}

Kegiatan pada tahap ini menentukan kompetensi yang ingin dicapai, konsep penyampaian isi bahan ajar, gambar, artikel, contoh-contoh yang dibutuhkan dan format penilaian produk. Desain produk dilakukan juga untuk merancang strategi yang akan digunakan, dan tes acuan patokan digunakan untuk mengetahui peningkatan keterampilan sosial

\section{Tahap Pengembangan}

Tahap ini dilakukan pengembangan dan pemilihan bahan-bahan yang digunakan dalam pengembangan bahan ajar seperti, memilih materi pelajaran, menyusun kisi-kisi keterampilan sosial, membuat RPP dan membuat kisi-kisi uji validasi ahli materi dan ahli media. Materi yang dikembangkan hanya materi sistem pembayaran. Validasi media dilakukan oleh 2 dosen ahli media, sedangkan validasi materi dilakukan oleh dosen dan guru. Keterampilan sosial yang akan diteliti hanya pada aspek kerjasama, komunikasi dan tanggungjawab sosial.

\section{Tahap Implementasi}

Uji coba dilakukan dengan dua tahap yakni, uji coba terbatas dan uji coba lapangan. Pada tahap ini juga dilakukan pre-test dan posttest pada pembelajaran. Kelas eksperimen yaitu kelas dengan pembelajaran bahan ajar berbasis problem based learning dan kelas kontrol dengan pembelajaran biasa. Pre-test dan posttest dilakukan untuk mengetahui peningkatan keterampilan sosial peserta didik dan untuk mengetahui prestasi peserta didik. Hal itu untuk pertimbangan bahan ajar sebagai media pembelajaran, bahwa tidak hanya meningkatkan keterampilan sosial tetapi juga dapat meningkatkan prestasi belajar peserta didik

\section{Tahap Evaluasi}

Evaluasi dilakukan untuk merevisi isi bahan ajar berbasis problem based learning dan untuk mengetahui keberhasilan dalam pencapaian bahan ajar untuk meningkatkan keterampilan sosial peseta didik. Hasil evaluasi merupakan langkah dalam mendapatkan produk akhir bahan ajar berbasis problem based learning untuk meningkatkan keterampilan sosial peserta didik.

\section{Uji Coba Produk}

Desain Uji Coba

Uji coba dilakukan tiga yaitu (1) uji ahli untuk menguatkan dan meninjau ulang produk, serta memberikan masukan perbaikan. Produk awal divalidasi terlebih dahulu oleh ahli materi dan media. Ahli materi terdiri dari dosen ekonomi dan guru mata pelajaran ekonomi SMA N 1 Godean, sedangkan ahli media terdiri dari 2 dosen ahli media. (2) uji coba terbatas yang dilakukan pada kelompok kecil kelas X IPS 2 terdiri dari 9 peserta didik. (3) uji lapangan untuk memperoleh data yang empiris dan teruji. Uji lapangan dilakukan dikelas X IPS 1 terdiri dari 30 peserta didik. Pada uji lapangan peneliti dibantu guru dan teman sejawat dalam melakukan observasi untuk melihat keterampilan sosial peserta didik.

\section{Instrumen Pengumpulan Data Angket}

Angket adalah daftar pertanyaan atau pernyataan yang diberikan kepada orang lain yang bersedia memberikan respon sesuai dengan permintaan pengguna (Riduwan, 2009, 
p.99). Lembar angket digunakan untuk memperoleh data kelayakan bahan ajar berbasis problem based learning dari ahli materi, ahli media, guru mata pelajaran ekonomi, dan peserta didik. Angket untuk ahli materi, media dan guru berupa angket validasi produk untuk memperoleh kelayakan dan saran yang nantinya menjadi bahan pertimbangan untuk revisi, sedangkan angket untuk peserta didik untuk mengetahui keterampilan sosial peserta didik.

\section{Tabel.1 Kisi-Kisi Instrumen Keterampilan} Sosial

\begin{tabular}{|c|c|c|}
\hline No & Aspek & Indikator \\
\hline 1 & Bekerjasama & $\begin{array}{ll}\text { a. Dapat bekerja aktif dalam } \\
\text { kelompok } \\
\text { b. } \\
\text { Menerima gagasan-ga- } \\
\text { gasan yang dihadirkan } \\
\text { dalam sebuah situasi } \\
\text { tugas kelompok yang } \\
\text { berbeda dari gagasan } \\
\text { sendiri. } \\
\text { c. Menyelesaikan perma- } \\
\text { salahan bersama-sama } \\
\text { dengan kelompok }\end{array}$ \\
\hline 2 & Komunikasi & $\begin{array}{l}\text { a. Membantu menulis de- } \\
\text { ngan baik } \\
\text { b. Menjadikan aktif me- } \\
\text { nyampaikan pendapat } \\
\text { c. Menyampaikan pen- } \\
\text { dapat/presentasi dengan } \\
\text { jelas }\end{array}$ \\
\hline 3 & $\begin{array}{l}\text { Tanggung- } \\
\text { jawab sosial }\end{array}$ & $\begin{array}{l}\text { a. Dapat berpartisipasi da- } \\
\text { lam menyelesaikan tugas } \\
\text { kelompok } \\
\text { b. Kesesuaian bahan ajar } \\
\text { mendorong peserta didik } \\
\text { untuk bekerjasama } \\
\text { c. Bahan ajar mendorong } \\
\text { peserta didik dapat men- } \\
\text { yampaikan pendapat }\end{array}$ \\
\hline
\end{tabular}

\section{Observasi}

Observasi digunakan untuk mengetahui keterampilan sosial peserta didik selama proses pembelajaran. Observasi dilakukan oleh guru dan teman sejawat. Ada 3 aspek yang diamati pada keterampilan sosial peserta didik, yaitu bekerjasama, komunikasi, dan tanggungjawab sosial.

\section{Teknik analisis Data}

\section{Validitas dan Reabilitas}

Suatu instrumen dikatakan valid apabila mempunyai validitas tinggi dan sebaliknya, instrumen kurang valid berarti validitasnya rendah (Arikunto, 2006, p.168). Dalam validitas internal digunakan pendapat para ahli (judment experts), dalam penelitian ini dosen dan guru ekonomi, sedangkan validitas eksternal dilakukan di SMA N 1 Sleman.

Reliabel artinya dapat dipercaya, jadi dapat diandalkan. Dalam mengetahui reliabilitas tes prestasi belajar dan angket digunakan bantuan Program Staticical Product and service solution (SPSS) 17.00 (dengan taraf kepercayaan $95 \%$ ).

\section{Angket}

Angket ahli materi dan ahli media digunakan untuk mengukur kelayakan bahan ajar berbasis problem based learning dengan skala (1) sangat kurang baik, (2) kurang baik, (3) cukup baik, (4) baik, (5) sangat baik. Sedangkan angket keterampian sosial untuk peserta didik dengan skala yang digunakan adalah (1) sangat tidak setuju, (2) kurang setuju, (3) cukup setuju, (4) setuju/baik, (5) sangat setuju. Data yang telah terkumpul dihitung rata-rata kemudian dikategorikan. Pengkategorian skor menurut Sudijono (2008, p.175).

Tabel.2 Kategori Skor

\begin{tabular}{|c|c|}
\hline Batas & Kategori \\
\hline $\mathrm{M}+1,5 \mathrm{SD}<\mathrm{X}$ & Sangat baik \\
\hline $\mathrm{M}+0,5 \mathrm{SD}<\mathrm{X}$ & Baik \\
\hline $\mathrm{M}-0,5 \mathrm{SD}<\mathrm{X}$ & Cukup \\
\hline $\mathrm{M}-1,5 \mathrm{SD}<\mathrm{X}$ & Kurang \\
\hline $\mathrm{X} \leq \mathrm{M}-1,5 \mathrm{SD}$ & Sangat kurang baik \\
\hline
\end{tabular}

Untuk melihat peningkatan pada pretest dan post-test kelas eksperimen dan kelas kontrol digunakan penghitungan dengan presentase untuk membantu hasil penghitungan rata-rata kategori.

\section{Observasi}

Pemberian skor untuk mengetahui keterampilan sosial peserta didik, alternatif jawaban pada lembar observasi yaitu: 0 tidak 
melakukan indikator, dan 1 melakukan indikator. Hasil observasi kemudian dihitung ratarata dan dikategorikan

Tabel.3 Kisi-kisi Observasi Keterampilan Sosial

\begin{tabular}{|c|c|c|}
\hline No & Aspek & Indikator \\
\hline 1 & Bekerjasama & $\begin{array}{l}\text { a. Dapat bekerja aktif dalam } \\
\text { kelompok } \\
\text { b. Peserta didik mengerja- } \\
\text { kan tugas bersama-sama } \\
\text { dengan kelompok }\end{array}$ \\
\hline 2 & Komunikasi & $\begin{array}{l}\text { a. Peserta didik mampu } \\
\text { menuliskan gagasanya } \\
\text { b. Peserta didik aktif me- } \\
\text { nyampaikan pendapat }\end{array}$ \\
\hline 3 & $\begin{array}{c}\text { Menunjukkan } \\
\text { Tanggung- } \\
\text { jawab sosial }\end{array}$ & $\begin{array}{l}\text { a. Menyelesaikan tugas ber- } \\
\text { sama tepat waktu } \\
\text { b. Partisipasi dalam } \\
\text { menyelesaikan tugas } \\
\text { kelompok }\end{array}$ \\
\hline
\end{tabular}

\section{Uji Pra Syarat}

Dilakukan uji normalitas untuk mengetahui distribusi dari semua variabel yang diteliti berdistribusi normal atau tidak, untuk menguji normalitas dari masing-masing skor digunakan SPSS Kolmagrov-Sminrov sebagai uji normalitas dengan taraf signifikan 5\%.

Uji homogenitas digunakan untuk mengetahui homogenitas antara 2 kelompok atau lebih. Uji homogenitas menggunakan hasil dari MANOVA.

\section{Uji MANOVA}

Uji MANOVA digunakan untuk mengetahui ada atau tidaknya perbedaan signifikansi secara statistik pada beberapa variabel yang terjadi secara serentak antara beberapa tingkatan dalam satu variabel. Untuk mengetahui perbedaan antar grup pada MANOVA dilakukan uji bersama-sama dan uji per variabel. Uji bersama-sama (multivariate significant tets) dilakukan dengan pillai's Trace, Wilk's Lambda, Hotteling's Trace dan Roy's Largest Root.

\section{HASIL DAN PEMBAHASAN}

Data Validasi Ahli

Validasi dilakukan oleh 2 ahli materi dan 2 ahli media.
Tabel.4 Kriteria Skor Angket Bahan Ajar

\begin{tabular}{|c|c|}
\hline Batas & Kategori \\
\hline $4,01<X$ & Sangat baik \\
\hline $3,34<X \leq 4,01$ & Baik \\
\hline $2,67<X \leq 3,34$ & Cukup \\
\hline $2,00<X \leq 2,67$ & Kurang \\
\hline$X<2,00$ & Sangat kurang baik \\
\hline
\end{tabular}

Hasil skor yang diperoleh oleh 2 ahli materi jika dikategorikan termasuk dalam kategori sangat baik pada aspek isi dan aspek kebahasaan. Skor aspek isi yaitu 4,43 dan 4,85 sedangkan aspek kebahasaan skor yang diperoleh yaitu 4 dan 4,71. Ahli materi juga telah menyatakan produk layak digunakan, sehingga produk dapat digunakan sebagai uji coba.

Hasil perhitungan skor dari ahli media ke-1 pada aspek penyajian yaitu 4,14 termasuk dalam kategori sangat baik, sedangkan pada aspek tampilan skor yang diperoleh 4,28 yaitu dalam kategori sangat baik. Pada validator ke-2 hasil perhitungan skor pada aspek penyajian 3,85 termasuk dalam kategori baik. Pada aspek tampilan diperoleh skor 4 termasuk dalam kategori sangat baik. Secara umum pada aspek media termasuk dalam kategori sangat baik, setelah validator menyatakan bahan ajar layak, maka bahan ajar tersebut digunakan untuk uji coba.

Hasil angket tanggapan peserta didik dalam uji coba terbatas menunjukkan skor 3,94 yaitu produk dalam kategori baik. Hasil uji coba lapangan dari 30 peserta didik skor yang diperoleh semua aspek bahan ajar termasuk dalam kategori baik yaitu 3,67.

\section{Hasil Validasi dan Reabilitas}

Hasil analisis uji coba angket dengan jumlah 9 butir pernyataan setelah dianalisis menggunakan SPSS 17.0 terdapat 1 butir angket yang tidak valid (Corrected Item-Total Correlation) karena nilainya 0,234. Angket yang tidak valid tersebut tidak dibuang tetapi dilakukan perbaikan, sehingga jumlah angket yang akan digunakan tetap 9 butir, dengan nilai r pada taraf kepercayaan 95\%. Hasil dari tabel reliabilitas di kolom Cronbach's Alpha menunjukkan nilai 0,727 dan interpretasi nilai $r$ da- 
lam kategori tinggi.

\section{Angket Observasi}

Hasil observasi pada kelas eksperimen pada kategori sangat baik ada kenaikan 6 peserta didik dari 20 peserta didik menjasi 26 peserta didik, sehingga ada kenaikan 20\% dalam kategori sangat baik. Kategori baik mengalami penurunan $20 \%$ dari 8 peserta didik menjadi 2 peserta didik. Hasil observasi yang dilakukan di kelas kontrol menunjukkan skor keterampilan sosial pada pembelajaran tanpa bahan ajar berbasis problem based learning dalam kategori sangat baik ada peningkatan $9,1 \%$, sedangkan pada kategori baik ada kenaikan 31,8\%, kategori cukup mengalami penurunan $22,7 \%$, kategori kurang menurun 4,5\% dan kategori sangat kurang baik mengalami penurunan 13,6\%. Hal tersebut menunjukkan keterampilan sosial pada pembelajaran dengan bahan ajar berbasis problem based learning pada kelas eksperimen mengalami kenaikan lebih baik dari kelas kontrol.

\section{Uji Pra Syarat Normalitas}

Hasil penghitungan normalitas menggunakan SPSS Asymp. Sig. (2-tailed) pre-test dan post-test kelas eksperimen dan kelas kontrol pada variabel kerjasama, komunikasi, tanggungjawab sosial dan Prestasi belajar menunjukkan nilai signifikansi lebih besar dari 0,05 maka dapat dikatakan variabel tersebut membentuk distribusi normal.

\section{Uji Pra Syarat Homogenitas}

Hasil uji MANOVA Box's M pada pretest adalah 0,189 maka variabel kerjasama, komunikasi, tanggungjawab sosial dan prestasi belajar memiliki varian-kovarian yang sama antara kelas eksperimen dan kelas kontrol. Hasil pengujian MANOVA pada post-test Box's M menunjukkan nilai 0,170, maka variabel kerjasama, komunikasi, tanggungjawab sosial dan prestasi belajar memiliki varian-kovarian yang sama antara kelas eksperimen dan kelas kontrol.

\section{Uji MANOVA}

Hasil pre-test uji MANOVA multivariat Pillai's Trace, Wilks' Lambda, Hotelling's Trace, Roy's Largest Root signifikansi yang diperoleh adalah 0,432. Hal tersebut menunjukkan bah- wa Sig. $\geq 0,05$ sehingga kelas yang akan dijadikan kelas eksperimen dan kelas kontrol tidak menunjukkan perbedaan terhadap prestasi belajar dan keterampilan sosial berupa kerjasama, komunikasi dan tanggungjawab sosial.

Pada post-test uji MANOVA multivariat Pillai's Trace, Wilks' Lambda, Hotelling's Trace, Roy's Largest Root nilai signifikansi 0,000. Hal tersebut menunjukkan bahwa Sig. $\leq 0,05$ sehingga kelas eksperimen dan kelas kontrol menunjukkan perbedaan terhadap prestasi belajar dan keterampilan sosial berupa kerjasama, komunikasi dan tanggungjawab sosial.

\section{Saran dari Peserta didik}

Beberapa saran dan masukan dari peserta didik yaitu pertama, bahan ajar untuk jenjang SMA menarik, materinya mudah dipahami, dan mendorong untuk lebih suka membaca dan bahan ajar ini menambah pengetahuan menjadi lebih luas. Kedua, pemberian gambar dan ilustrasi pada bahan ajar menarik dan mempermudah pemahaman. Ketiga, bahan ajar yang diberikan sebaiknya 1 orang mendapatkan 1 bahan ajar, supaya dapat dibaca di rumah. Keempat, bahan ajar sudah baik, tetapi saat presentasi sebaiknya semua peserta didik diberi kesempatan untuk menyampaikan hasil diskusi. Kelima, latihan-latihan pada bahan ajar membantu untuk memahami kenyataan dalam masyarakat.

\section{SIMPULAN}

Pengembagan bahan ajar berbasis problem based learning pada penelitian ini menggunakan model pengembangan Dick\&Carey yang dijadikan 5 tahap yaitu, analisis kebutuhan, desain pengembangan, produk awal, evaluasi, produk akhir. Hasil uji kelayakan bahan ajar berbasis problem based learning dari 2 ahli materi ditinjau dari kelayakan isi pada kategori skor sangat baik dan kelayakan kebahasaan dalam skor kategori sangat baik, sehingga dapat dikatakan dari aspek materi bahan ajar berbasis problem based learning dalam kategori skor sangat baik. Sedangkan uji kelayakan dari 2 ahli media, ditinjau dari tampilan pada kategori sangat baik dan baik, sedangkan jika ditin- 
jau dari penyajian dalam kategori skor sangat baik 4. Maka dapat dikatakan ahli media memberikan penilaian dalam kategori sangat baik terhadap bahan ajar berbasis problem based learning. Untuk hasil Uji MANOVA setelah bahan ajar berbasis problem based learning digunakan dalam pembelajaran di kelas ekperimen menunjukkan adanya perbedaan dengan kelas kotrol.

\section{UCAPAN TERIMA KASIH}

Terima kasih kepada semua rekanrekan yang membantu proses penelitian ini, terima kasih selanjutnya kami ucapkan kepada tim redaksi yang telah memuat artikel ini. Semoga dapat memberikan manfaat dan kontribusi yang besar.

\section{DAFTAR PUSTAKA}

Amir, Taufiq. (2009). Inovasi pendidikan melalui problem based learning. Jakarta: Kencana.

Arends, R. (2012). Learning to teach ninth edition. New York. McGraw-Hill

Arikunto, Suharsimi. (2006). Prosedur penelitian. Jakarta: Rineka Cipta.
Depdiknas. (2013). Peraturan Pemerintah RI Nomor 32 Tahun 2013, tentang Standar Nasional Pendidikan

Depdiknas. (2008). Panduan pengembangan bahan ajar. Di ambil pada tanggal 21 Desember 2012, dari http://researchengines. com/ christiana6-04.html.

Dick, W \& Carey, L. (2005). The systematic design of intruction. New York: Longman

Goleman, D. (2004). Emotional intelligence. Jakarta: Gramedia

Hamalik, Oemar. (2005). Proses belajar mengajar. Jakarta: Bumi Aksara.

Harefa, Andrias. (2004). Menjadi manusia pembelajar. Jakarta: Kompas media.

Karyana, Yana. (2006). Ekonomi SMA. Yogyakarta: Pustaka Pelajar

Riduwan. (2009). Metode dan teknik menyusun tesis. Bandung: Alfabeta

Riyanto, Yatim. (2010). Paradigma baru pembelajaran. Jakarta: Kencana

Sukmadinata, N. S. (2013). Metode penelitian pendidikan. Bandung: Rosda Karya

Zuchdi, Darmiyati. (2010). Humanisasi pendidikan. Jakarta: Bumi Aksara. 